\title{
ТЕХНОЛОГИЧЕСКАЯ СХЕМА ПРОЦЕССА ВЫПОЛНЕНИЯ КОМПЛЕКСНЫХ КАДАСТРОВЫХ РАБОТ ПО ЭТАПАМ
}

\section{Евгения Геннадвевна Чубатова}

Сибирский государственный университет геосистем и технологий, 630108, Россия, г. Новосибирск, ул. Плахотного, 10, обучающийся, тел. (913)469-08-61, e-mail: evgesha-perfileva@mail.ru

В статье рассмотрено понятие комплексные кадастровые работы. Описаны этапы, необходимые при выполнении комплексных кадастровых работ в Российской Федерации. Представлена технологическая схема процесса выполнения комплексных кадастровых работ на современном этапе развития.

Ключевые слова: комплексные кадастровые работы, кадастровый инженер, заказчик, карта - план, технологический процесс, земельный участок, метод определения координат

\section{TECHNOLOGICAL SCHEME OF THE PROCESS OF IMPLEMENTATION OF INTEGRATED CADASTRE WORKS IN STAGES}

\section{Evgenia G. Chubatova}

Siberian State University of Geosystems and Technologies, 10, Plakhotnogo St., Novosibirsk, 630108, Russia, Student, phone: (913)469-08-61, e-mail: evgesha-perfileva@mail.ru

The article discusses the concept of complex cadastral work. The stages required for complex cadastral works in the Russian Federation are described. The flowchart of the process of performing complex cadastral works at the present stage of development is presented.

Keywords: complex cadastral works, cadastral engineer, customer, map - plan, technological process, land plot, method for determining coordinates

Для того что бы понимать всю процедуру, применяемую при выполнении комплексных кадастровых работ (ККР), необходимо составить технологическую схему всего процесса. Такая схема поможет точечно отслеживать все этапы процедуры выполнения ККР и оперативно реагировать на какие-либо изменения в ходе работ.

Для начала рассмотрим, что же подразумевает под собой комплексные кадастровые работы (ККР). Согласно Федерального закона № 221-Ф3 от 24.07.2007 «О кадастровой деятельности» [1]. ККР - это кадастровые работы, которые выполняются в отношении земельных участков, зданий и сооружений, объектов 
незавершенного строительства, расположенных на территории кадастрового квартала или нескольких смежных кадастровых кварталов [1].

Выполнение комплексных кадастровых работ условно можно разделить на четыре этапа.

Первым этапом можно считать заключение контракта.

Между исполнителем (кадастровым инженером) и заказчиком заключается контракт на выполнения ККР работ в соответствии с действующим законодательством. Далее исполнитель уведомляет правообладателей объектов, находящихся в границах территории кадастрового квартала о начале работ. Также на этом этапе исполнитель собирает и подготавливает все необходимые документы для выполнения комплексных кадастровых работ.

Вторым этапом является выбор метода выполнения ККР.

Исполнитель выбирает актуальный метод определения координат характерных точек земельного участка, ориентируясь на его расположение. Такой метод может быть: геодезический, аналитический, картометрический, спутниковых измерений, фотограмметрический. Так же на данном этапе идет формирование картографической основы (карты, планы в растровом и векторном формате и ортофотоматериалы) в соответствии с Единой электронной картографической основой (ЕЭКО) [3].

Заключением на данном этапе является разработка карты-плана территории кадастрового квартала, в границах которого, проводился комплекс кадастровых работ.

Третий этап заключается в утверждении заказчиком карты - плана, согласование местоположений земельных границ с согласовательной комиссией и подготовка окончательной редакции карты - плана в формате XML или на бумажном носителе для передачи в Единый государственный реестр недвижимости (ЕГРН) [3].

И заключительным этапом в выполнении ККР является передача картыплана территории кадастрового квартала, в отношении которого проводился комплекс кадастровых работ, в ЕГРН. Далее данные будут отражены в Публичной кадастровой карте на портале Росреестра.

На основании описания этапов выполнения ККР, составим графический вид технологической схемы. Такая схема наглядно покажет весь процесс работы выполнения ККР, что позволит отслеживать на каждом этапе какие-либо изменения и оперативно на них реагировать.

На рисунке представлена технологическая схема по выполнению ККР на территории кадастрового квартала. 


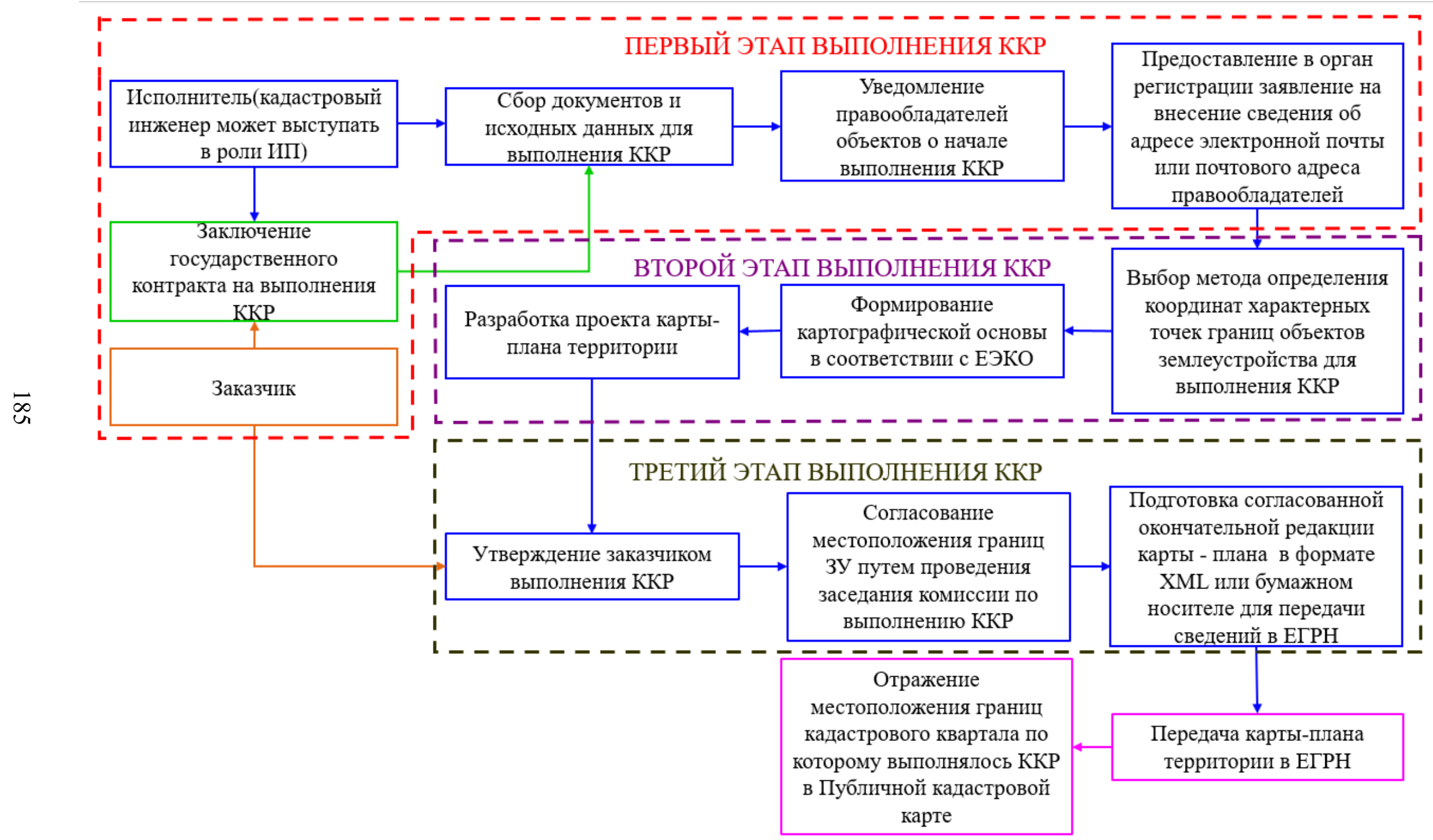

Схема технологического процесса выполнения комплексных кадастровых работ 


\section{БИБЛИОГРАФИЧЕСКИЙ СПИСОК}

1. Федеральный закон от 13.07.2015№ 221-Ф3 (последняя редакция) [Электронный ресурс] - Режим доступа: http://www.consultant.ru/document/-cons_doc_LAW_70088/ (дата обращения 17.10.2020).

2. Федеральный закон от 24.07.2007 № 218-Ф3 (последняя редакция) [Электронный ресурс] - Режим доступа: http://www.consultant.ru/document/cons_doc_LAW_182661/ (дата обращения 15.06.2019).

3. Официальный сайт РОСРЕЕСТРА [Электронный ресурс] - Режим доступа: https://rosreestr.ru/site/ (дата обращения 15.06.2019).

4. Основные понятия в области ведения государственного кадастра недвижимости [Электронный ресурс] - Режим доступа: https://studfiles.net/preview/1838312/ (дата обращения 15.06.2019).

5. О важности наличия в ЕГРН достоверных сведений об объектах не-движимости [Электронный ресурс] - Режим доступа: http://old.dizo31.ru/index.php/571-o-vazhnosti-nalichiya-vegrn-dostovernykh-svedenij-ob-ob-ektakh-nedvizhimosti/ (дата обращения 15.06.2019).

6. Кадастровая деятельность и кадастровые инженеры [Электронный ре-сурс], режим доступа: https://rosreestr.ru/site/press/news/kadastrovayadeyatelnost-i-kadastrovye-inzhenery/ (дата обращения 15.06.2019).

(C) Е. Г. Чубатова, 2021 